НАУКОВИЙ ВІСНИК

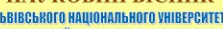
РИНАРНОї МЕДИЦИНИ ТА БОТТЕНОЛО, імені с.3. гжицького Scientific messenger of Livi National Unirersity
Veterinary Medicine and Biotechnologies

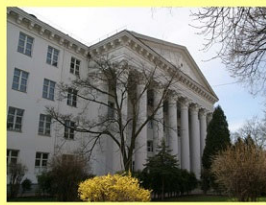

СЕРІЯ “ЕКономІчн НАУКИ"

Том 21 № 93 2019

Науковий вісник Львівського національного університету ветеринарної медицини та біотехнологій імені С.3. Гжицького. Серія: Економічні науки

\author{
Scientific Messenger of Lviv National University \\ of Veterinary Medicine and Biotechnologies. \\ Series: Economical Sciences
}

UDC $658(075)$

\title{
Management functions: their unity and interdependence in the processes of activity
}

\author{
M. Shulskyi \\ Stepan Gzhytskyi National University of Veterinary Medicine and Biotechnologies Lviv, Ukraine
}

Article info

Received 10.09.2019

Received in revised form 09.10 .2019

Accepted 10.10.2019

Stepan Gzhytskyi National University of Veterinary Medicine and Biotechnologies Lviv, Pekarska Str., 50, Lviv, 79010, Ukraine.

Tel.: +38-097-569-77-12 E-mail: Pretty62@ukr.net

Shulskyi, M. (2019). Management functions: their unity and interdependence in the processes of activity. Scientific Messenger of Lviv National University of Veterinary Medicine and Biotechnologies. Series: Economical Sciences, 21(92), 58-62. doi: 10.32718/nvlvet-e9312

In the article the detailed functions of management are investigated both in the general interpretation and in the context of their classification into general and specific. The research process takes into account the achievements of well-known researchers in this field of public relations, one of which is, Hamilton Church is shown in the epigraph to this publication, and its fruitful activities are shown in Table 1. The research materials for the selected topic are presented in a logical sequence. Thus, in particular, information on management functions and their role in different spheres of activity is shown in Table 2 (materials on the essence of basic management functions are also presented here); Table 3 provides information on specific management functions and their classification. It focuses on the features that are most used in their classification. Studies of the dialectical interrelation of general and specific management functions, their results are presented in Table 4. The answers to the questions we have formed fully reveal these interrelations. The conclusions follow from the results of the conducted research. They have some theoretical and practical significance. Implementation of the presented proposals in production conditions will increase the efficiency of management activities.

Key words: management functions, general and specific management functions, managerial activity, public relations, dialectic, interconnection.

\section{Функції менеджменту: їх сдність і взаємозалежність у процесах здійснення діяльності}

\author{
М.Г. Шульський
}

Львівський національний університет ветеринарної медицини та біотехнологій імені С.3. Гжиџького, м. Львів, Украӥна

В статті у деталізованих формах проведено дослідження діючих функиій менеджменту як у загальному трактуванні, так $і$ в розрізі їх класифікачії на загальні та конкретні. У процесах проведення досліджень взято до уваги здобутки відомих дослідників у цій сфері суспільних відносин, висловлювання одного з яких, а саме: Гамільтона Черча наведено в епіграфі до даної публікацї, а його плідна діяльність відображена в таблиці 1. Матеріали досліджень за обраною темою представлено у певній логічній послідовності. Так, зокрема, інформація щуоо функиій менеджменту та їх роль у різних сферах здійснення діяльності наведена у таблиuүi 2 (тут також представлено матеріали щуодо сутті основних функцій менеджменту); в таблиці 3 наведено інформацію про конкретні функцї менеджменту та їх класифікацію. Тут сконщентровано увагу на ті ознаки, які в найбільшій мірі використовуються при здійсненні їх класифікації. Дослідження діалектичного взаємозв'язку загальних і конкретних функиій менеджменту, їх результати представлені у таблиці 4. Відповіді на сформовані нами питання у повній мірі розкривають ці взаємозв 'язки. Висновки випливають із результатів проведених досліджень. Вони мають певне теоретичне і практичне значення. Реалізація представлених пропозицій у виробничих умовах дозволить підвищити ефективність управлінської діяльності.

Ключові слова: функиії менеджменту, загальні і конкретні функиії менеджсменту, управлінська діяльність, суспільні відносини, діалектика, взаємозв'язок. 


\section{Вступ}

Слова, що винесені в епіграф даної статті, у повній мірі відображають те планетарне значення функцій менеджменту в сфері людської діяльності різних іiі видах. Перш за все, ніж з'ясувати суть передбачених досліджень, сконцентруємо увагу на ті основні складові даної публікації, які обумовили їі підготовку. Як відомо, проведення реформ у різних сферах суспільних відносин вимагає якісно нових підходів до здійснення насамперед управлінської діяльності 3 врахуванням змін умов зовнішнього і внутрішнього середовища. А ці умови, як встановлено науковими дослідженнями, не $€$ константами, а характеризуються постійними і динамічними змінами як з позитивними, так і негативними результатами, які необхідно постійно досліджувати і вносити певні елементи регулювання у сфери людської діяльності. А це забезпечується, перш за все, результативним використанням функцій менеджменту, вивчення яких, за висловлюванням Г. Черча, має колосальне значення. Все це сказане відображає мету підготовки даної статті та іiі значення для ефективного здійснення менеджерської діяльності.

Аналіз останніх досліджень $і$ публікаиій. Дослідження функцій менеджменту у різних сферах суспільних відносин завжди було в центрі уваги дослідників минулих, теперішніх i, на наше переконання, буде предметом дослідження майбутніх поколінь. Серед минулих і сучасних дослідників, слід відзначити таких як: В.Г. Галанець, Й.С. Завадський, Г.О. Колесніков, М. Мартиненко, С.І. Михайлов, В.Г. Федоренко, Ф.І. Хміль та інші.
Одночасно зауважимо, що функції менеджменту не $\epsilon$ застиглою формою функціонування різних сфер людської діяльності, а вони постійно та динамічно змінюються і розвиваються під впливом різних факторів. Саме ці обставини спонукають до продовження подальших досліджень даної теми, що нами і зроблено.

\section{Результати та їх обговорення}

Функціонування різних сфер суспільних відносин здійснюється під впливом дії різноманітних чинників розвитку, важливими серед яких є функції менеджменту, що забезпечують проведення управлінської діяльності у різних складових людського суспільства. 3 цього приводу варто повернутися до суті слів, виражених Г. Черчем, які у повній мір відображають значення дослідження функцій управління. Враховуючи важливість досліджень цього вченого до теми нашого вивчення, ми вважаємо за необхідне сказати про нього дещо більше. Для цього використаємо діалоговий метод дослідження (він буде домінувати у подальших наших дослідженнях за даною темою). Зібрані і певним чином оброблені матеріали представлені у таблиці 1.

Отож, народився Г. Черч у XIX столітті (1866 р.) i відійшов у потойбічний світ у XX столітті (1936р.). Його творча діяльність здійснювалася на зламі віків, а в цей час, як відомо, відбувалися епохальні зміни у всіх сферах людської діяльності. Якими проблемами він займався б, яких би результатів досягнув - все це представлено у вищезгаданій таблиці 1.

\section{Таблиця 1}

Коротка характеристика діяльності Г. Черча (Shchokin et al., 2007)

\begin{tabular}{|c|c|c|}
\hline $\begin{array}{l}\text { № } \\
\Pi / \Pi\end{array}$ & Питання, сформовані нами & Відповіді із тексту вищевказаного джерела \\
\hline 1 & $\begin{array}{l}\text { Хто такий Черч Гамільтон і де були } \\
\text { сформовані його основні теоретичні } \\
\text { висновки? }\end{array}$ & $\begin{array}{l}\text { Черч Гамільтон (1866-1936) - представник американської школи науки про } \\
\text { управління. Основні теоретичні висновки досліджень Черча викладено у } \\
\text { його праці “Основи управління виробництвом” }\end{array}$ \\
\hline 2 & Що є основним надбанням Г. Черча? & $\begin{array}{l}\text { Основним надбанням Черча } є \text { розгляд функціональних засад управління. } \\
\text { Він стверджував, що загальна мета виробництва реалізується шляхом син- } \\
\text { тезу п’яти органічних функцій }\end{array}$ \\
\hline 3 & Які це $\epsilon$ органічні функції? & $\begin{array}{l}\text { Цими органічними функціями є проектування, облік, оперування, облад- } \\
\text { нання і розпорядництво (контроль) }\end{array}$ \\
\hline 4 & $\begin{array}{l}\text { Які складові має мистецтво управ- } \\
\text { ління виробничим підприємством? }\end{array}$ & $\begin{array}{l}\text { Мистецтво управління виробничим підприємництвом має дві складові: } \\
\text { перша - визначення органічних функцій, їх найвигідніших пропорцій, } \\
\text { друга - правильний аналіз }\end{array}$ \\
\hline 5 & $\begin{array}{l}\text { Що повинно відповідати кожній із } \\
\text { п’яти специфічних цілей? }\end{array}$ & $\begin{array}{l}\text { Кожній з п’яти специфічних цілей мусить відповідати особливий апарат, } \\
\text { що має завдання досягнення цієї мети й проведення її в життя }\end{array}$ \\
\hline 6 & Як розглядати кожну таку мету? & $\begin{array}{l}\text { Тому кожну таку мету треба розглядати як точне вираження особливої } \\
\text { органічної функції через проектування }\end{array}$ \\
\hline 7 & $\begin{array}{l}\text { Що визначив Г. Черч, розглядаючи } \\
\text { організацію виробництва? }\end{array}$ & $\begin{array}{l}\text { Розглядаючи організацію виробництва, Г. Черч визначає етапи практичної } \\
\text { побудови організаційних функцій }\end{array}$ \\
\hline
\end{tabular}

Не будемо деталізувати наведений матеріал, адже він у конкретизованих формах відображений в табличній формі. Однак звернемо увагу на те, що погляди Г. Черча $\epsilon$ важливими і актуальними в умовах сьогодення і тому їх дослідження, як він виразився, “що вивчення функцій має колосальне значення” і ми у повній мірі підтримуємо знамениті твердження дослідника та продовжимо їх дослідження у нашій публікації. Перш за все відзначимо, що дослідження проводимо від загального до конкретного, матеріалізуючі одержані результати представлено у деталізованих твердженнях, заключеннях і висновках. 
Таблищя 2

Функції менеджменту та їх роль у різних сферах здійснення діяльності (Shchokin et al., 2007)

\begin{tabular}{|c|c|c|}
\hline $\begin{array}{l}\text { № } \\
\text { П/ח } \\
\end{array}$ & Питання, сформовані нами & Відповіді із тексту вищевказаного джерела \\
\hline 1 & $\begin{array}{l}\text { Як трактуються функції менедж- } \\
\text { менту? }\end{array}$ & $\begin{array}{l}\text { Функції менеджменту - сукупність спеціалізованих видів управлінської } \\
\text { діяльності, спрямованих на узгодження спільних дій і операцій працівників } \\
\text { організації з метою досягнення певних цілей }\end{array}$ \\
\hline 2 & Що означає термін “функція”? & Термін “функція” (лат. / functio) означає здійснення, виконання \\
\hline 3 & $\begin{array}{l}\text { Що вдалося забезпечити за допо- } \\
\text { могою функцій менеджменту? }\end{array}$ & $\begin{array}{l}\text { За допомогою функцій менеджменту вдається забезпечити безперервність, } \\
\text { динамічність, послідовність та цілеспрямованість управлінського процесу, } \\
\text { розчленувати та закріпити окремі види робіт за виконавцями }\end{array}$ \\
\hline 4 & $\begin{array}{l}\text { Коли сформувалися функції мене- } \\
\text { джменту? }\end{array}$ & $\begin{array}{l}\text { Функції менеджменту сформувалися під час удосконалення поділу і спеці- } \\
\text { алізації праці, відображають сутність і зміст управлінської діяльності на } \\
\text { всіх рівнях управління }\end{array}$ \\
\hline 5 & $\begin{array}{l}\text { Що було підставою класифікації } \\
\text { менеджменту? }\end{array}$ & $\begin{array}{l}\text { Підставою для класифікації функції менеджменту є вид управлінської } \\
\text { діяльності, що дає змогу відрізнити одну роботу від інших у процесі вироб- } \\
\text { ничого циклу }\end{array}$ \\
\hline 6 & $\begin{array}{l}\text { Які функції виділяють за цією } \\
\text { ознакою? }\end{array}$ & $\begin{array}{l}\text { За цією ознакою виділяють загальні (основні) та конкретні (специфічні) } \\
\text { функції }\end{array}$ \\
\hline 7 & $\begin{array}{l}\text { Які є загальні функції і що вони } \\
\text { зумовлюють? }\end{array}$ & $\begin{array}{l}\text { Загальні функції, до яких відносять планування, організовування, мотиву- } \\
\text { вання, контролювання і координування (регулювання), зумовлені спеціалі- } \\
\text { зацію управлінської праці незалежно від сфери діяльності суб'єкта госпо- } \\
\text { дарювання }\end{array}$ \\
\hline 8 & $\begin{array}{l}\text { Що формують загальні функції і в } \\
\text { якій послідовності? }\end{array}$ & $\begin{array}{l}\text { Формують управлінський процес у такій послідовності: 1) розроблення } \\
\text { управлінських рішень; 2) здійснення заходів щодо реалізації прийнятих } \\
\text { рішень; 3) організація контролю за реалізацією рішень }\end{array}$ \\
\hline
\end{tabular}

Матеріли, що наведені у таблиці 2, дають можливість простежити процеси розвитку функцій менеджменту від загального їх представлення суті до конкретизації цього, що за допомогою їх досягаються. Отож, функції менеджменту - це сукупність тих видів управлінської діяльності, які дозволяють досягти поставлених цілей (відповіді на перше питання таблиці 2). При цьому слід зауважити про походження самого терміну “функціі”. Він походить, як відзначено у відповіді на 2-ге питання, від латинського слова “function", що означає здійснення, виконання. Таким чином, можна стверджувати, що поняття функції має давнє історичне походження і сьогоднішнє використання цього поняття, як стверджував Г. Черч, має “колосальне значення".

Ось саме $з$ позицій Г. Черча продовжимо подальші дослідження функцій менеджменту, основні складові які представлено в таблиці 2. Одночасно зауважимо, що як в цій частині статті, так в попередній і в наступних нами покладено використання матеріалів понятійно-термінологічного словника менеджменту (Shchokin et al., 2007). В літературі з менеджменту функції менеджменту трактуються в основному так, як це відображено у відповіді на перше питання таблиці 2. Не менш цінна інформація представлена у відповіді на 3-тє питання, в якій чітко сформовано, що вдалося досягти за допомогою функцій менеджменту. А досягнення були грандіозні - забезпечення результативності управлінського процесу шляхом розчленування та закріплення окремих видів робіт за виконавцями. Відправною точкою цих процесів стали зміни щодо класифікації функцій менеджменту (відповіді на 4-5-те питання). Відпо- віді на 7-8-ме питання дають представлення про загальні функції менеджменту та їх роль і значення у формуванні управлінських процесів у певній логічній послідовності.

Крім основних функцій менеджменту, важливу роль у сферах управлінської діяльності відіграють конкретні функції менеджменту. Інколи їх ще називають специфічними (Khmil, 2003), дехто вважає їх спеціальними (Zavadskyi, 1998) та ін. Однак теорія визначає, а практика констатує, що саме ці функції управління безпосередньо забезпечують вплив суб'єктів управління на об'єкти. Як би їх не формували, як би не ілюстрували б, як би не називали б, всетаки їх основна направленість здійснюється в цьому, що їх “функція” виокремлена відповідно до завдань управління діяльності організації, або до конкретних стадій виробничого процесу, або за спрямованістю на конкретні чинники виробництва (Khmil, 2003).

Одночасно слід зауважити, що конкретні функції не $є$ однорідними, а вони є різнорідними i, отже, класифікуються за різними ознаками. Відповідь на комплексне питання 3 дають змогу уяснити цю класифікацію і констатувати, що це все, що тут представлено, матеріалізується у конкретних діях управлінського персоналу, який здійснює управлінські функції щодо керування конкретним підприємством.

Одночасно відзначимо, що управлінці здійснюють свої конкретні функції не ізольовано від основних функцій, а в їх тісному діалектичному взаємозв'язку, взаємопоєднані і взаємодоповнені. Все це у деталізованих формах відображено в таблиці 4. 
Таблиця 3

Конкретні функції менеджменту та їх класифікація (Shchokin et al., 2007)

\begin{tabular}{|c|c|c|}
\hline $\begin{array}{l}\text { № } \\
\text { ㄱ/ }\end{array}$ & Питання, сформовані нами & Відповіді із тексту вищевказаного джерела \\
\hline 1 & $\begin{array}{l}\text { Як трактуються конкретні функції } \\
\text { менеджменту? }\end{array}$ & $\begin{array}{l}\text { Це види управлінської діяльності, які забезпечують формування способів } \\
\text { управлінського впливу та забезпечують конкретні управлінські процеси; } \\
\text { відображають сутність і зміст управлінської діяльності на всіх рівнях } \\
\text { управління }\end{array}$ \\
\hline 2 & $\begin{array}{l}\text { В яких сферах діяльності організації } \\
\text { задіяні конкретні функції менеджме- } \\
\text { нту? }\end{array}$ & $\begin{array}{l}\text { Конкретні (специфічні) функції задіяні в усіх сферах діяльності організа- } \\
\text { ції та виокремлюються відповідно до конкретних стадій виробничого } \\
\text { процесу }\end{array}$ \\
\hline \multirow[t]{5}{*}{3} & $\begin{array}{l}\text { За якими ознаками найбільш поши- } \\
\text { рена класифікація конкретних функ- } \\
\text { цій: }\end{array}$ & \\
\hline & $\begin{array}{l}\text { 1) за впливом на весь процес управ- } \\
\text { ління }\end{array}$ & $\begin{array}{l}\text { (перспективне, поточне, економічне та соціальне планування; управління } \\
\text { основним виробництвом, допоміжним виробництвом, постачанням; } \\
\text { організація робіт зі стандартизації; облік і звітність; економічний аналіз; } \\
\text { зовнішньоекономічна діяльність тощо); }\end{array}$ \\
\hline & $\begin{array}{l}\text { 2) за впливом на окремі стадії ви- } \\
\text { робничого процесу }\end{array}$ & $\begin{array}{l}\text { (організація виробництва; управління технічною підготовкою виробниц- } \\
\text { тва; управління технологічними процесами; технічний контроль і випро- } \\
\text { бування; збут продукції); }\end{array}$ \\
\hline & 3) за об’єктом управління & $\begin{array}{l}\text { (управління підприємством, цехом, службою, відділом, дільницею, бри- } \\
\text { гадою тощо); }\end{array}$ \\
\hline & $\begin{array}{l}\text { 4) за впливом на окремі елементи } \\
\text { виробництва }\end{array}$ & $\begin{array}{l}\text { (управління організацією праці та заробітної плати; капітальне виробни- } \\
\text { цтво; управління фінансами і маркетинговою діяльністю та ін.) }\end{array}$ \\
\hline
\end{tabular}

\section{Таблиця 4}

Діалективний взаємозв’язок загальних і конкретних функцій менеджменту (Shchokin et al., 2007)

\begin{tabular}{|c|c|c|}
\hline $\begin{array}{l}\text { № } \\
\Pi / \Pi\end{array}$ & Питання, сформовані нами & Відповіді із тексту вищевказаного джерела \\
\hline 1 & $\begin{array}{l}\text { Коли абстрактний стан загальних } \\
\text { функцій набуває відповідних ознак? }\end{array}$ & $\begin{array}{l}\text { Між функціями менеджменту існує тісний взаємозв'язок. Абстрактний } \\
\text { стан загальних функцій набуває відповідних ознак лише в процесі реалі- } \\
\text { зації конкретних функцій, і навпаки }\end{array}$ \\
\hline 2 & $\begin{array}{l}\text { Що дозволяє сформувати усвідом- } \\
\text { лення взаємозв'язку між загальними } \\
\text { і конкретними функціями? }\end{array}$ & $\begin{array}{l}\text { Усвідомлення діалектичного взаємозв'язку між загальними і конкретни- } \\
\text { ми функціями дає змогу формувати ефективну систему менеджменту, } \\
\text { усувати дублювання та бюрократичні перепони в їі функціонуванні тощо }\end{array}$ \\
\hline 3 & $\begin{array}{l}\text { Що забезпечує реалізацію загальних } \\
\text { і конкретних функцій у їх тісному } \\
\text { взаємозв'язку? }\end{array}$ & 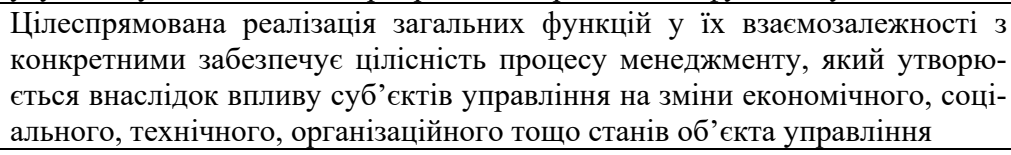 \\
\hline 4 & $\begin{array}{l}\text { Завдяки чого реалізовуються конк- } \\
\text { ретні функції? }\end{array}$ & $\begin{array}{l}\text { Конкретні функції відображають процес, об’єкт управління або елемент } \\
\text { виробничо-господарської діяльності, реалізуються завдяки застосуванню } \\
\text { загальних функцій (планування, організування, мотивування, контролю- } \\
\text { вання і регулювання) }\end{array}$ \\
\hline 5 & $\begin{array}{l}\text { При яких умовах загальні функції } \\
\text { трансформуються в конкретні? }\end{array}$ & $\begin{array}{l}\text { Загальні функції менеджменту з абстрактних трансформуються в конкре- } \\
\text { тні лише через управління певними об’єктами, процесами, елементами } \\
\text { виробничо-господарської діяльності, тобто набувають відповідного зміс- } \\
\text { ту, будучи задіяними в реалізації конкретних функцій менеджменту }\end{array}$ \\
\hline 6 & $\begin{array}{l}\text { Що дає дослідження взаємозв'язку } \\
\text { функцій менеджменту? }\end{array}$ & $\begin{array}{l}\text { Дослідження взаємозв'язку функцій забезпечує вдосконалення управлін- } \\
\text { ня, формування ефективної системи менеджменту, усунення зайвих ла- } \\
\text { нок, бюрократичних перепон, подолання опору змінам }\end{array}$ \\
\hline 7 & $\begin{array}{l}\text { При яких умовах загальні функції } \\
\text { перетворюються на реальну управлі- } \\
\text { нську діяльність? }\end{array}$ & $\begin{array}{l}\text { Загальні функції є абстрактними і перетворюються на реальну управлін- } \\
\text { ську діяльність лише тоді, коли з їх допомогою реалізуються конкретні } \\
\text { функції. Тому загальні функції розглядають як основу здійснення будь- } \\
\text { якого управлінського процесу }\end{array}$ \\
\hline 8 & $\begin{array}{l}\text { Завдяки якій операції здійснюється } \\
\text { послідовність виконання функцій } \\
\text { управління у просторі і часі? }\end{array}$ & $\begin{array}{l}\text { Послідовність виконання функцій управління у просторі та часі здійсню- } \\
\text { ється завдяки такій операції, як цикл менеджменту. Розпочинається він з } \\
\text { формулювання мети, головних завдань, які виступають підставою для } \\
\text { розроблення системи заходів щодо їх досягнення та економічного і соціа- } \\
\text { льного забезпечення }\end{array}$ \\
\hline
\end{tabular}

Отож, загальні функції менеджменту (планування, організування, мотивація, контроль) є “абстрактивними i перетворються на реальну управлінську діяльність лише тоді, коли з їх допомогою реалізовуються функції менеджменту конкретні” (Shchokin et al., 2007). Як це відбувається у конкретних виробничих умовах? Це 
можна прослідкувати на конкретному прикладі, скажімо, щодо розвитку тваринництва в господарстві, зокрема для виконання конкретної функції: управління технікою та технологічною підготовкою виробництва, яка реалізовується за допомогою загальних функцій менеджменту: планування техніко-технологічної підготовки виробництва; організування роботи різних служб (ветеринарної медицини, зооінженерної та інших) i підрозділів; матеріального та морального стимулювання працівників служб; контролювання здійснення процесів та внесення відповідних змін у діяльності задіяних служб з врахуванням та усунення виявлених недоліків та упущень.

Поглиблюючись в матеріали таблиці 4 “Діалектичний взаємозв'язок загальних і конкретних функцій менеджменту", можна поставити цілком закономірно питання, а що дає цей відзначений взаємозв'язок функцій? Відповіді сформуємо на основі інформації, що представлена у вищезгаданій таблиці, у певній логічній послідовності, а саме:

- абстрактний стан загальних функцій трансформується в реальність лише в процесах використання конкретних функцій i, навпаки, тому загальні функції розглядають як основу здійснення будь-якого процесу управління (відповідь на перше, 5 і 7-ме питання);

- діалектичний взаємозв'язок між досліджуваними функціями дає змогу сформувати результативну систему менеджменту та усунути виявлені недоліки, забезпечити цілісність процесів менеджменту (відповідь на 2-3-тє питання);

- взаємозв'язок функцій, їх детальне вивчення забезпечує вдосконалення управління, формування ефективної системи менеджменту та, що головне, усунення бюрократичних перепон і подолання опору змінами (відповідь на 6-те питання);

- виконання функцій менеджменту у їх діалектичному взаємозв'язку, взаємозалежності і взаємодоповнені у просторі та часі в певній логічній послідовності здійснюються завдяки такій операції, як цикл менеджменту. Головні складові цього процесу: формування мети, головних завдань, розроблення заходів щодо їх досягнення та ін. Все це повинно бути направлено на досягнення позитивних зрушень в економіці та підвищення рівня соціального забезпечення населення (відповідь на 8-ме питання). Отож, за висловлюванням I. Хміля: “За змістом цикл менеджменту - це послідовність виконання функцій менеджменту" (Khmil, 2003).
Нами наведено, на наш погляд, лише основні складові системи діалектичного взаємозв'язку загальних і конкретних функцій менеджменту. Існують інші взаємозв'язки, які в більшій і меншій мірі впливають на ефективність здійснення управлінської діяльності.

\section{Висновки}

На основі проведеного дослідження встановлено тісний діалектичний взаємозв'язок основних i конкретних функцій менеджменту в процесах здійснення управлінської діяльності у різних сферах суспільних відносин. Проте на практиці управлінський персонал не завжди своєчасно усвідомлює важливість цих взаємозв'язків, що в кінцевому підсумку негативно впливає на ефективність управлінської праці. Саме тому у виробничих умовах розв'язання цих проблем слід приділяти належну увагу.

Перспективи подальших досліджень. Зміна внутрішнього і зовнішнього середовища у процесах проведення реформ істотно впливає на системи взаємозв'язків основних і конкретних функцій в процесах здійснення управлінської діяльності. Саме ці зміни слід досліджувати як у сучасних умовах, так i на перспективу.

\section{References}

Fedorenko, V.H. (2015). Menedzhment: pidruchnyk. 3-tie vyd., pererob y dopov. K.: Alerta (in Ukrainian).

Galanec, V.G. (1978). Jeffektivnost upravlenija: teorija metodika, praktika. Lvov: Vishha shk. (in Russian).

Khmil, F.I. (2003). Osnovy menedzhmentu: K.: Akademvydav (in Ukrainian).

Kolesnikov, H.O. (2007). Menedzherskyi slovnyk: Navchalno-dovidkove vydannia. K.: "VD" Profesional" (in Ukrainian).

Martynenko, M.M. (2005). Osnovy menedzhmentu. Pidruchnyk. K. Karavela (in Ukrainian).

Mykhailov, S.I. (2012). Menedzhment [tekst]: navch. posib. 2-he vyd. vypr. ta dop. K.: "Tsentr uchbovoi literatury" (in Ukrainian).

Shchokin, H.V., Holovatyi, M.F., Antonenko, O.V., \& Sladkevych, V.P. (2007). Menedzhment: Poniatiinoterminolohichnyyi slovnyk. K.: MAUP (in Ukrainian).

Zavadskyi, Y.S. (1998). Menedzhment: Management. T.1. Vyd. 2-e. K.: Ukrainsko-finskyi instytut menedzh-mentu i biznesu (in Ukrainian). 